\title{
A rare lumbar spinal column injury: Glass injury
}

\section{Ender bir spinal kolon yaralanması: Cam yaralanması}

\author{
İbrahim TOKER, Özge DUMAN ATİLLA, Turgay Yılmaz KILIÇ, Osman TAŞ, Serkan HACAR \\ Tepecik Ĕ̈itim ve Araştırma Hastanesi, Acil Tıp Klinĭ̆i, İzmir
}

\begin{abstract}
Penetrating injuries to the vertebral column and the spinal cord are rare. Cauda equina injury caused by broken glass shards is even rarer than expected. In this study, a case of spinal column injury was reported in a 25 -year-old female patient with glass shards stabbed in to her back, after falling back on top of the table made of glass. A piece of stabbed glass shards was extracted and the wound was sutured at another hospital before she presented to our emergency service. At the time of presentation, the patient had 2/5 muscle strength on her right leg and hypoesthesia below the L4 level. After emergency surgical intervention, the sensory deficit and the muscle strength have completely improved, and the patient was discharged after 6 days. In penetrating traumas to the lumbar region, emergency physician must keep possible spinal column injury in mind.
\end{abstract}

Key words: Lumbar vertebra/injury, wounds, penetrating/diagnosis

$\ddot{0} \mathbf{Z}$

Spinal kolon ve spinal kordun penetran yaralanmaları enderdir. Cam kırılmasına bağlı cauda equina yaralanması beklenenden daha enderdir. Bu makalede cam masa üzerine düşme sonrası, sırtına cam saplanması nedeniyle spinal kolon yaralanması olan 25 yaşında bir kadın hasta sunulmuştur. Hastanın acil servisimize gelmeden önce başka bir hastanede saplanan cam parçasının bir parçası çıkarılmış ve yarası dikilmişti. Hastanın başvurusu sırasında sağ bacakta $2 / 5$ kas gücü ve L4 seviyesinin altında hipoestezisi mevcuttu. Acil cerrahi müdahale sonrası hastada duyu ve motor defisit tamamen düzelmiş ve hasta operasyondan 6 gün sonra taburcu edilmişti. Lomber bölgeye olan penetran travmalarda, acil tıp hekimi spinal kolon yaralanması olabileceğini akılda bulundurmalıdır.

Alındı̆̆ı tarih: 16.03.2016

Kabul tarihi: 17.05 .2016

Yazışma adresi: Uzm. Dr. İbrahim Toker, İzmir Tepecik Eğitim ve Araştırma Hastanesi, Acil Tıp Kliniği Gaziler Caddesi No:468, Yenişehir 35120 İzmir

Anahtar kelimeler: Lomber vertebra/yaralanma, yaralanmalar, penetran/tanı

e-mail: ibrahimtoker9@gmail.com

\section{INTRODUCTION}

Injuries to the spinal cord have high morbidity rate and affects commonly young, healthful persons ${ }^{(1)}$. Stabbing injuries to the spinal cord, also named nonmissile penetrating spinal injuries (NMPSI) are unusual in clinical practice ${ }^{(2)}$. A nation-wide epidemiological study in Turkey showed that nonmissile penetrating injuries involve $\% 3.3$ of all spinal injuries ${ }^{(3)}$.

We present a case with neurological deficit due to penetrating injury in the lumbar region which resolved after surgery.

\section{CASE REPORT}

A 25-year-old woman applied to the emergency department (ED) with chief complaint of weakness in the right leg after falling back on the top of the table made of glass. A piece of stabbed glass was removed and the wound was sutured at another hospital before she presented to our ED. Her vital signs were within normal limits and a linear sutured laceration, approximately $4 \mathrm{~cm}$ in length, on the right paraspinal region at the L4 level was revealed. At the time of presentation, the patient had muscle strength of $2 / 5$ on 
her right leg and hypoesthesia below the L4 level.

Computed tomography revealed foreign bodies in spinal column and paraspinal structures, soft tissue edema, hematoma and air in spinal canal, while magnetic resonance imaging confirmed narrowing of the spinal canal (Figure 1).

The patient was taken up for surgery. Emergency laminectomy and hematoma evacuation were performed after 2 hours after her admission into ED. Six pieces of glass seen in paravertebral space, lumbar 2-3 interlaminal space and inside of the vertebral column were removed under direct vision and she underwent duraplasty (Figure 1). After operation, the sensory deficit and the muscle strength have comple-

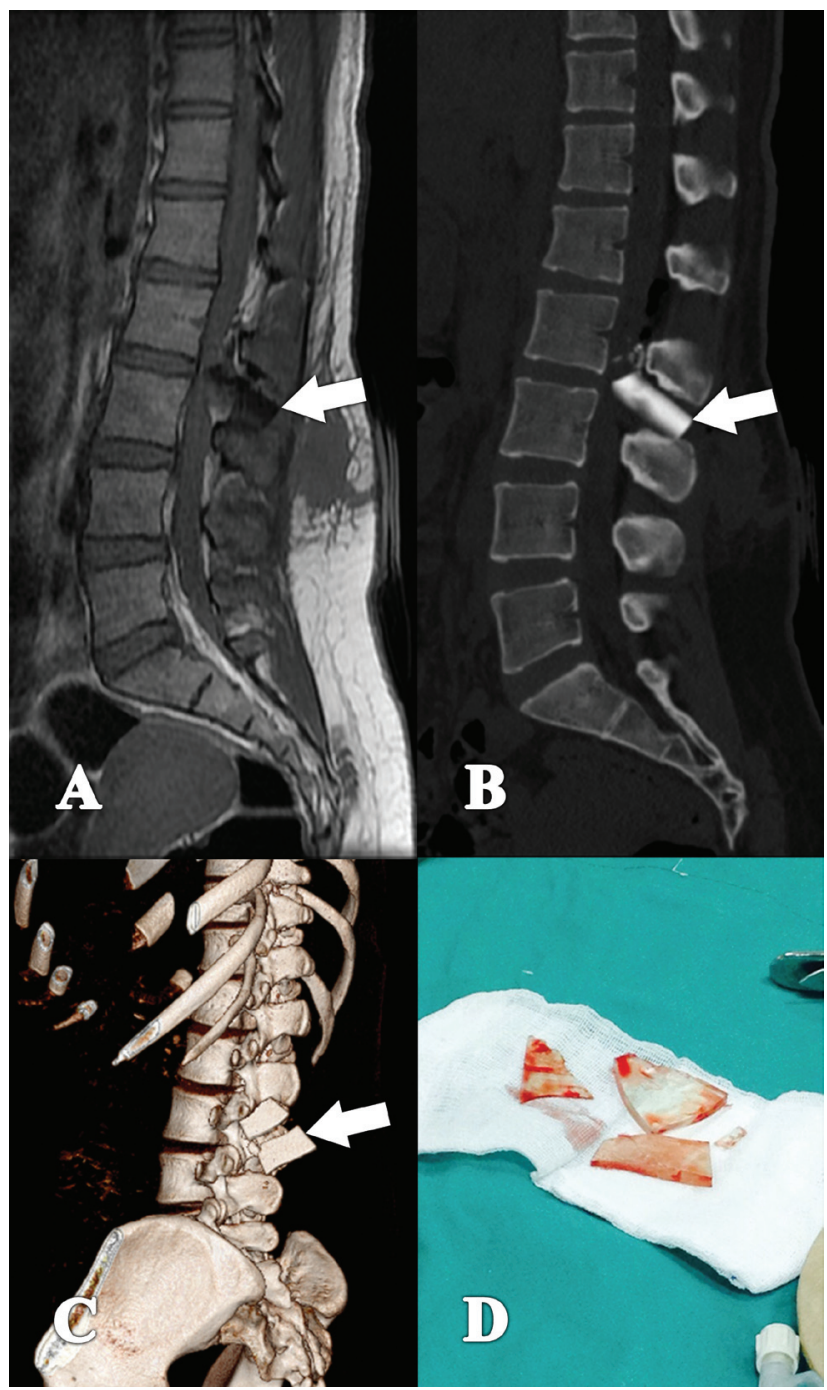

Figure 1. tely improved, and patient was discharged at 6th postoperative day.

\section{DISCUSSION}

Spinal cord injuries (SCIs) are among serious health problems, commonly resulting in significant morbidity and permanent neurological sequelae ${ }^{(4)}$. Gunshot or stab wounds are common causes of penetrating injuries to the vertebral column. In addition, bizarre penetrating objects as seen in our case are reported to cause spinal cord injuries ${ }^{(2,5)}$. Peacock et al. ${ }^{(6)}$ reported a study on 450 patients with stab wounds of spinal cord. Apart from this study, global literature only includes fewer case reports and small series. In our case, glass pieces penetrated into the lumbar region revealed and entered the spinal canal by traversing the L2-3 facet joint.

The American Spinal Injury Association (ASIA) impairment scale can be used to sort the degrees of the injury and is a good predictor of neurologic outcome ${ }^{(7)}$ (Table 1). Following SCI, factors affecting neurologic recovery are etiology and severity of injury. Neurological improvement is more common in incomplete injuries ${ }^{(8)}$. Marino et al. ${ }^{(10)}$ found that $\% 66.7$ of the patients with grade $\mathrm{C}$ had progressed to grade $\mathrm{D}$ and only $\% 3.8$ of the patients with grade $\mathrm{C}$ had progressed to grade $\mathrm{E}$ in 1 year. In our case, the patient was assessed as a grade $\mathrm{C}$ by ASIA classification and the lesion progressed to grade E at discharge ${ }^{(9)}$.

Table 1. ASIA impairment scale.

\begin{tabular}{ll}
\hline Category & Description \\
\hline Grade A & $\begin{array}{l}\text { Complete. No motor or sensory function is preserved in the } \\
\text { sacral segments S4-S5 }\end{array}$ \\
Grade B & $\begin{array}{l}\text { Sensory incomplete. Sensory but not motor function is preser- } \\
\text { ved below injury level and includes S4-S5 (Motor complete) }\end{array}$ \\
Grade C & $\begin{array}{l}\text { Motor incomplete. Motor function is preserved below the neuro- } \\
\text { logical level, and more then half of key muscles below the neu- } \\
\text { rological level have a muscle grade less then } 3 \text { (Grade 0 to 2) } \\
\text { Motor incomplete. Motor function is preserved below the } \\
\text { neurological level, and more then half of key muscles below } \\
\text { the neurological level have a muscle grade greater than or } \\
\text { equal to 3 (Grade } \geq 3)\end{array}$ \\
Gormal. Motor and sensory function are normal
\end{tabular}

ASIA: American Spinal Injury Association 
Because of capability to show foreign objects, bony fragments, intravertebral and paravertebral hematoma, CT scan is a suitable imaging technique for the patients with NMPSI. On CT scan, a metallic object like blade may produce streak artifacts, but this defect aids in localization of tip of blade ${ }^{(11)}$.

In SCI, MRI demonstrates medulla spinalis compression, ligamentous and vascular injuries and also can show trajectory of missile, spinal contusion and vertebral hematoma. But there are some safety concerns such as migration of metallic object during MR imaging. Because of this reason the physician should consider additional possible injury ${ }^{(1,12)}$.

Most of the spinal cord injuries require nonoperative treatment. Decision of operation should be considered if the patient has a potential for neurological recovery and neural element compression exists. Regardless of initial neurologic status, surgical intervention is critical for neurologic outcome ${ }^{(11,13,14)}$.

The optimal timing of surgical intervention for spinal cord injury is controversial. Early decompression ( $<24 \mathrm{hr}$ ) should be considered as main stream of the therapeutic management of any patient with SCI, especially those with cervical SCI ${ }^{(15)}$. In our case, early decompression within 24 hours was performed and full neurologic recovery occurred.

In conclusion, patients with penetrating trauma to the lumbar region should be assessed for spinal cord injury. When SCI is suspected, immediate medical assessment is essential. In this case, the patient's diagnosis was missed before being presented to our ED. Because of this reason, in emergency medicine, initial neurologic examination is essential for penetrating spinal cord injuries.

\section{REFERENCES}

1. Sundgren PC, Philipp M, Maly PV. Spinal trauma. Neuroimaging Clinics of North America 2007;17:73-85. http://dx.doi.org/10.1016/j.nic.2006.11.006

2. Rabiu TB, Aremu AA, Amao OA, Awoleke JO. Screw driver: an unusual cause of cervical spinal cord injury. BMJ Case Reports 2011;2011.

3. Karacan I, Koyuncu H, Pekel O, Sumbuloglu G, Kirnap M, Dursun H, et al. Traumatic spinal cord injuries in Turkey: a nation-wide epidemiological study. Spinal Cord 2000;38:697701. http://dx.doi.org/10.1038/sj.sc.3101064

4. Seecharan DJ, Arnold PM. Spinal Cord Injuries and Syndromes. In: Shen FH, Samartzis D, Fessler RG, editors. Textbook of the Cervical Spine: Elsevier Inc.; 2015. p.192-6.

5. Komarowska M, Debek W, Wojnar JA, Hermanowicz A, Rogalski M. Brown-Sequard syndrome in a 11-year-old girl due to penetrating glass injury to the thoracic spine. European journal of orthopaedic surgery \& traumatology: Orthopedie Traumatologie 2013;23(Suppl 2):S141-3.

6. Peacock WJ, Shrosbree RD, Key AG. A review of 450 stabwounds of the spinal cord. South African Medical Journal = Suid-Afrikaanse Tydskrif Vir Geneeskunde 1977;51:961-4.

7. Kirshblum SC, Burns SP, Biering-Sorensen F, Donovan W, Graves DE, Jha A, et al. International standards for neurological classification of spinal cord injury (revised 2011). The Journal of Spinal Cord Medicine 2011;34:535-46. http://dx.doi.org/10.1179/204577211X13207446293695

8. Vazquez XM, Rodriguez MS, Penaranda JM, Concheiro L, Barus JI. Determining prognosis after spinal cord injury. Journal of Forensic and Legal Medicine 2008;15:20-3. http://dx.doi.org/10.1016/j.jflm.2007.06.003

9. White JP, Thumbikat P. Acute spinal cord injury. Surgery (Oxford) 2012;30:326-32. http://dx.doi.org/10.1016/j.mpsur.2012.05.005

10. Marino RJ, Ditunno JF, Jr., Donovan WH, Maynard F, Jr. Neurologic recovery after traumatic spinal cord injury: data from the Model Spinal Cord Injury Systems. Archives of Physical Medicine and Rehabilitation 1999;80:1391-6. http://dx.doi.org/10.1016/S0003-9993(99)90249-6

11. Goyal RS, Goyal NK, Salunke P. Non-missile penetrating spinal injuries. The Indian Journal of Neurotrauma 2009;6:81-4. http://dx.doi.org/10.1016/S0973-0508(09)80035-X

12. Moyed S, Shanmuganathan K, Mirvis SE, Bethel A, Rothman M. MR imaging of penetrating spinal trauma. AJR American Journal of Roentgenology 1999;173:1387-91. http://dx.doi.org/10.2214/ajr.173.5.10541126

13. Clarke MJ, Narayan RAJ, Witham TF. Management of Penetrating Injuries to the Spine. In: Quinones-Hinojosa A, Auguste K, Ogilvy CS, Hoh BL, Rigamonti D, Eskandar E, et al., editors. Schmidek and Sweets Operative Neurosurgical Techniques: Indications, Methods and Results. Sixth ed: Elsevier; 2005. p. 2047-54.

14. Li X, Curry EJ, Blais M, Ma R, Sungarian AS. Intraspinal penetrating stab injury to the middle thoracic spinal cord with no neurologic deficit. Orthopedics 2012;35:e770-3. http://dx.doi.org/10.3928/01477447-20120426-40

15. Lee HJ, Kim HS, Nam KH, Han IH, Cho WH, Choi BK. Neurologic Outcome of Laminoplasty for Acute Traumatic Spinal Cord Injury without Instability. Korean Journal of Spine 2013;10:133-7. http://dx.doi.org/10.14245/kjs.2013.10.3.133 